PRACE NAUKOWE UNIWERSYTETU EKONOMICZNEGO WE WROCLAWIU

\title{
Agnieszka Mrozińska
}

Uniwersytet Ekonomczny w Poznaniu

e-mail: agnieszka.mrozinska@ue.poznan.pl

\section{WYBRANE MIASTA WOJEWÓDZKIE \\ I ICH OTOCZENIE W PROCESIE ADAPTACJI STRUKTUR PODMIOTÓW GOSPODARCZYCH NOWYCH SEKTORÓW GOSPODARKI}

\section{SELECTED CAPITALS OF VOIVODESHIPS \\ AND THEIR NEIGHBORING AREAS \\ IN THE ADAPTATION PROCESS OF STRUCTURES \\ OF ENTITIES OF NATIONAL ECONOMY \\ IN NEW ECONOMY SECTORS}

DOI: $10.15611 /$ pn.2017.477.18

JEL Classification: O10, R11

\begin{abstract}
Streszczenie: Problematyka badawcza artykułu dotyczy oceny przeobrażeń strukturalnych gospodarki miast wojewódzkich i ich najbliższego sąsiedztwa. Celem artykułu jest porównanie procesów zmian w strukturze gospodarczej wybranego miasta do procesów zmian w strukturze gospodarczej jego najbliższego otoczenia na przykładzie dziewięciu wybranych obszarów. W artykule dokonano analizy procesu adaptacji struktur podmiotów gospodarczych stworzonych na podstawie sekcji PKD 2007. Kolejnym krokiem w analizie było przeprowadzenie tożsamego badania struktur podmiotów gospodarczych nowych sektorów gospodarki wyodrębnionych na podstawie działów sekcji J, K, L, M i N. W ocenie procesu przeobrażeń zastosowano metody badania struktur, uwzględniające intensywność, szybkość i monotoniczność zachodzenia zmian w okresie od 2009 do 2015 r. Do badania wybrano z 8 powiatów grodzkich: Białystok, Gorzów Wielkopolski, Kielce, Olsztyn, Opole, Poznań, Rzeszów, Toruń i Zieloną Górę oraz 8 otaczających je powiatów.
\end{abstract}

Słowa kluczowe: adaptacja, struktura gospodarcza, nowe sektory gospodarcze.

Summary: Research issues of the paper concern the evaluation of structural transformation of the provincial cities's economy and their immediate neighboring areas. The aim of the paper is to compare the processes of change in the economic structure of the city to the processes of change in the economic structure of its immediate surroundings on the example of 8 selected areas. In article it analyzes the process of adapting the structures of economic entities created under section PKD 2007. The next step in the analysis is to study the structures of economic entities of new sectors of the economy on the basis of separate sections $\mathrm{J}, \mathrm{K}, \mathrm{L}$, $\mathrm{M}$ and $\mathrm{N}$. To evaluate the process of change the methods of research structures were used, 
taking into account the intensity, the speed and the monotonicity of changes during the period from 2009 to 2015. The study selected 8 districts: Białystok, Gorzów Wielkopolski, Kielce, Olsztyn, Opole, Poznań, Rzeszów, Torun and Zielona Góra and 8 surrounding districts.

Keywords: adaptation, economic structure, new sectors of the economy.

\section{Wstęp}

Funkcjonowanie podmiotów gospodarczych w gospodarce warunkowane jest przez bliższe i dalsze otoczenie, które wpływa na decyzje podejmowane w procesie zarządzania. Złożoność systemu gospodarczego powoduje, że interpretacja zachodzących zmian jest utrudniona przez to, że najczęściej widzimy jedynie finalny efekt przeobrażenia, na który wpływały różne czynniki. W badaniu przemian nie pomaga także fakt, iż procesy rozwojowe nie zachodzą równomiernie w czasie i przestrzeni. Zdolność do adaptacji, czyli reagowania na zmieniające się warunki zewnętrzne i wewnętrzne, jest jedną z podstawowych cech charakteryzujących podmioty i struktury, które mają szanse przetrwać w obliczu narastającej zmienności warunków rozwoju w XXI w.

Celem artykułu jest porównanie procesów zmian w strukturze gospodarczej wybranego miasta $\mathrm{z}$ procesami zmian $\mathrm{w}$ strukturze gospodarczej jego najbliższego otoczenia na przykładzie dziewięciu wybranych obszarów. W pierwszej części artykułu przeanalizowano proces adaptacji struktur podmiotów gospodarczych stworzonych na podstawie sekcji PKD 2007. W drugiej części analizy przeprowadzono tożsame badanie struktur podmiotów gospodarczych nowych sektorów gospodarki, wyodrębnionych na podstawie działów sekcji J, K, L, M i N. W opracowaniu zastosowano metody badania struktur uwzględniające intensywność, szybkość i monotoniczność zachodzenia zmian w okresie od 2009 do 2015 r.

\section{Miasto i jego otoczenie jako lokalizacja procesów adaptacyjnych i rozwoju nowych sektorów gospodarki}

Podmioty gospodarcze, rozpatrywane jako szeroko pojęta struktura gospodarcza, są powiązane ze sobą i z terytorium, na jakim funkcjonują za pomocą lokalizacji poprzez określoną formę organizacji przestrzennej. W obfitej literaturze dotyczącej rozwoju regionalnego odnaleźć można wielkie miasto i jego otoczenie jako zagadnienie szczególnie często opisywane, zwłaszcza w kontekście różnic, jakie występują $\mathrm{w}$ procesie rozwoju społeczno-gospodarczego. Zidentyfikowane $\mathrm{w}$ teoriach korzyści aglomeracji, a więc korzyści płynące ze wspólnej lokalizacji i korzyści z urbanizacji, wpływają na skłonność podmiotów gospodarczych do sytuowania się w dużych ośrodkach miejskich bądź w ich bezpośrednim sąsiedztwie.

Tematykę relacji pomiędzy miastem a jego otoczeniem zapoczątkowały rozważania Perroux [1955], który zaobserwował, że wzrost gospodarczy nie jest widoczny 
jednocześnie na całym obszarze i że istnieją pewne miejsca, nazwane przez niego biegunami wzrostu, w których wzrost jest szczególnie widoczny. Koncepcję tę rozwinął później Boudeville [1966], który korzystając z teorii ośrodków centralnych Christallera [1933], zidentyfikował biegun wzrostu, na wzór ośrodka centralnego, jako zgrupowanie silnie powiązanych i dynamicznie rozwijających się działalności, które w przyszłości mogłyby wpłynąć na rozwój pozostałych działalności, utożsamionych z koncepcją obszaru uzupełniającego.

Nierównomierności rozwoju zauważone zostały także przez Hirschmanna [1985], który zaobserwował, że nierównomierności są nieuniknioną cechą procesów rozwojowych. Myrdal [1957], tłumacząc szybszy rozwój regionów mających korzystniejsze warunki do rozwoju, zaproponował koncepcję kumulatywnej przyczynowości. Teoria rozwoju spolaryzowanego, opublikowana przez Friedmanna [1967, 1972], mówiła o asymetrycznych relacjach pomiędzy obszarami, które są centrami i peryferiami. Relacja centrum-peryferie charakteryzowała się mechanizmami, które prowadziły do dominacji rdzenia, ale także mogła tworzyć struktury hierarchiczne.

Wspomniana wcześniej bogata literatura związana z identyfikacją i wyjaśnieniem relacji pomiędzy miastem a otoczeniem doczekała się wielu rozpraw empirycznych i przyniosła wnioski na temat nierównomierności procesów rozwoju przestrzeni, stwierdzała występowanie relacji miasto-otoczenie, a także odmienny przebieg procesów rozwojowych w obu obszarach [Szołek 2006; Domański 2008; Adamus 2009; Czyż 2009; Kudłacz 2009; Gaczek 2009; 2010; 2011].

Niekwestionowaną cechą rzeczywistości społeczno-gospodarczej jest zmienność obserwowana w czasie, która jest efektem dopasowywania się pewnych elementów istniejących systemów do nowych warunków otoczenia zewnętrznego i do modyfikacji wewnętrznych warunków funkcjonowania tych systemów. Warto zauważyć, że systemy społeczno-gospodarcze trwają w długim okresie, mimo że funkcjonują w warunkach permanentnej zmienności. Zdolność przetrwania, którą możemy rozumieć jako zdolność do absorpcji zakłóceń i dostosowania się do nowych warunków gospodarczych, przyrodniczych i społecznych, jest miarą organizacyjnej elastyczności systemów i historycznej trajektorii, wzdłuż której system się rozwija. Co więcej, sam proces adaptacji systemów nabiera szczególnego znaczenia w kontekście wzrostu gospodarczego.

W systemach adaptacyjnych, a za takie należy uznać systemy społeczno-gospodarcze, kluczowe dla zrozumienia procesów w nich zachodzących jest wyjaśnienie samotransformacji rozumianej jako proces powstawania makrostruktury z mikroróżnorodności. Szanse, jakie niesie za sobą wzrost wiedzy, rozumieć należy jako zmiany zewnętrzne lub wewnętrzne w stosunku do systemu, mogą one powodować zmiany w alokacji zasobów i struktur popytu, a przy sprzyjających warunkach powinny prowadzić do wzrostu gospodarczego. Niektórzy badacze twierdzą, że procesy rynkowe są sednem koordynacji mikroróżnorodności, a agregaty, które pojawiają się w ich rozumowaniu, są wynikiem interakcji między poszczególnymi rodzajami działalności gospodarczej [Metcafe i in. 2006]. Wymiar makroekonomiczny ich uzasad- 
nienia powinien się więc odnosić do powiązań, jakie występują w systemach [Domański 2012, s. 185-187].

Warunkiem zachodzenia zmian adaptacyjnych w systemie jest wewnętrzna różnorodność lub mechanizmy mogące wytwarzać różnorodność w miarę potrzeb [Allen i in. 2006, s. 24]. Mikroróżnorodność elementów przyczynia się do rozwoju i powstania całkiem nowych struktur systemu, przez co system staje się systemem o zmieniającej się różnorodności strukturalnej. Zwykle podtrzymywanie ukrytej różnorodności lub mechanizmu ją tworzącego wymaga ponoszenia kosztów, które najczęściej związane są z eksperymentowaniem, tworzeniem i komercjalizacją nowych technologii i przyczyniają się do tworzenia nowych bądź modyfikacji istniejących elementów struktury gospodarczej. W wyniku przeobrażeń szans oraz odpowiedzi na potrzeby zgłaszane przez rynek, które możemy rozumieć jako zmiany w otoczeniu, powstawać mogą nowe sektory gospodarki, szczególnie w zakresie niematerialnych usług opartych na wiedzy. Do takich branż i działalności zaliczyć możemy te, które obejmują m.in. branżę IT i oprogramowanie, aplikacje mobilne, druk 3D, bazy danych, gry komputerowe, przemysły kreatywne, badania naukowe, biotechnologię, nanotechnologię, a także usługi finansowe, ubezpieczeniowe oraz związane $\mathrm{z}$ administrowaniem.

\section{Adaptacja struktur podmiotów gospodarczych nowych sektorów gospodarczych w wybranych miastach i w ich otoczeniu}

Opisanie procesów adaptacyjnych gospodarki z uwzględnieniem terenów centralnych i peryferyjnych współczesnych miast wiązało się z koniecznością wybrania do badania takich ośrodków, które mogłyby w jednoznaczny sposób, poza sporami o poprawność metod delimitacji obszarów aglomeracyjnych, wskazywać na zależność pomiędzy centrum i otoczeniem. Ze względu na problem z dostępnością danych do analizy wybrano więc takie ośrodki miejskie, a ściślej miasta na prawach powiatu, które otoczone były tylko przez jeden sąsiadujący powiat. Były to następujące miasta: Białystok, Gorzów Wielkopolski, Kielce, Olsztyn, Opole, Poznań, Rzeszów, Toruń, Zielona Góra oraz sąsiadujące z nimi powiaty: białostocki, gorzowski, kielecki, olsztyński, opolski, poznański, rzeszowski, toruński, zielonogórski.

Opisując proces adaptacji gospodarki miast na prawach powiatu i powiatów, posłużono się danymi GUS, które dotyczyły liczby podmiotów gospodarczych, a podstawą do stworzenia struktury były sekcje PKD 2007. Dwudziestoelementowa struktura została stworzona dla każdego z powiatów w okresie od 2009 do 2015 r., co łącznie dało 126 struktur, które poddano analizie intensywności przeobrażeń strukturalnych. Wykorzystano miernik zwany kątem $\theta$ lub cosinusem kąta $\theta$, który stosowany jest w badaniach intensywności przeobrażeń. Do zalet tego miernika należy to, że nadaje on różną wagę takim samym przesunięciom w strukturze w zależności od 
wielkości zmienianego udziału, przez co pełniej oddaje istotę zmian strukturalnych [Wyżnikiewicz 1987, s. 69]. Wskaźnik opisany jest następującym wzorem:

$$
\cos \theta=\frac{\sum_{i=1}^{n} f_{i}^{0} f_{i}^{1}}{\sqrt{\sum_{i=1}^{n}\left(f_{i}^{0}\right)^{2}} \sqrt{\sum_{i=1}^{n}\left(f_{i}^{1}\right)^{2}}}
$$

gdzie: $f_{i}$ - udział $i$-tego elementu w populacji $(i=1,2, \ldots, n)$,

$f^{1}$ - udział elementu w strukturze badanej,

$f^{0}$ - udział elementu w strukturze bazowej.

Miernik ten osiąga wartość równą 1 dla struktur identycznych $\left(\right.$ kąt $\left.\theta=0^{\circ}\right)$ i wartość zerową przy maksymalnie dużej zmianie struktury $\left(\right.$ kąt $\left.\theta=90^{\circ}\right)$. W literaturze można znaleźć też przypadki użycia cosinusa kąta $\theta$, który z większą dokładnością pozwala ocenić zmiany, które występują najczęściej, czyli zmiany rzędu ok. $10^{\circ}$ [Moore 1978].

Po zbadaniu intensywności zachodzenia zmian oszacowano także szybkość i monotoniczność przeobrażeń [Kukuła 1996]. Miernik v opisuje wartość przeciętnej prędkości przekształceń strukturalnych w ujęciu dynamicznym $\mathrm{i}$ jest wyrażony średnią wartością łańcuchowych miar zróżnicowania struktur danego powiatu.

$$
v=\frac{\sum_{t=0}^{n=1} \sum_{i=1}^{k}\left|\alpha_{i t}-\alpha_{i(t+1)}\right|}{2 n},
$$

gdzie: $\alpha_{i}=\left[\begin{array}{c}\alpha_{1} \\ \alpha_{2} \\ \alpha_{k}\end{array}\right]$ - wektor struktury obiektu A, tak, że $\sum_{i=1}^{k} \alpha_{i}=100$,

$k$ - liczba składowych,

$t=(0,1, \ldots, t)$.

Inaczej mówiąc, miernik ten opisuje tempo przeobrażeń, natomiast kolejna użyta miara $-\eta$, opisuje proces przeobrażania się struktur. Wskaźnik $\eta$ obrazuje monotoniczność zmian strukturalnych i pozwala określić, czy ewolucja struktury utrzymuje względnie stabilny kierunek zmian:

$$
\eta=\frac{v_{m, 0}}{\sum_{t=0}^{m-1} v_{t, t+1}},
$$

gdzie: $v_{m, 0}$ - przeciętna prędkość przekształceń strukturalnych w badanym $m$-tym okresie w stosunku do struktury bazowej opatrzonej subskryptem 0 , $v_{t}$ - stopień zmian strukturalnych w czasie $t$.

Wartość wskaźnika monotoniczności przekształceń strukturalnych waha się od 0 do 1 . Im jest on wyższy (stopień monotoniczności bliższy 1), tym bardziej struktury ewoluują w sposób konsekwentny i są odporne na niestabilność, która może być powodowana przez chaotyczne przeobrażenia składowych, które w długim okresie i tak nie są przyczyną zmian struktury zastanej na początku okresu. 
Wartość miernika kąta $\theta$ może wahać się od $0^{\circ}$ do $90^{\circ}$, dlatego też można stwierdzić na podstawie przeprowadzonych analiz, że przeciętne przekształcenia struktury podmiotów gospodarczych były niewielkie. Wartości tego miernika, jakie osiągały powiaty, wahały się od $0,484^{\circ}$ do $6,409^{\circ}$, więc rozbieżność między poszczególnymi latami w strukturach nie była dość znaczna (tab. 1). Na podstawie analizy wybranych powiatów można zaobserwować, że tymi o najwyższej średniej intensywności zmian były miasta na prawach powiatu: Zielona Góra $\left(2,049^{\circ}\right)$ oraz Rzeszów $\left(2,041^{\circ}\right)$. Najmniejszą intensywnością zmian charakteryzowały się natomiast powiat opolski (średnio $0,928^{\circ}$ ) oraz miasto na prawach powiatu Gorzów Wielkopolski (średnio $0,975^{\circ}$ ). Największe zmiany w strukturze nastąpiły pomiędzy rokiem 2011 i 2012.

Analiza szybkości zachodzenia zmian w strukturze podmiotów gospodarczych w powiatach od 2009 do 2015 r. wskazała podobne prawidłowości, co analiza intensywności zmian struktury przedstawiona za pomocą wskaźnika Moore'a. Do powiatów, w których najszybciej zachodziły zmiany, należały miasta na prawach powiatu: Zielona Góra i Rzeszów, a także powiat toruński. Do najwolniejszych zmian doszło w Gorzowie Wielkopolskim, Kielcach, Opolu, a także w powiecie opolskim. Analiza monotoniczności wskazała te powiaty, których zmiany miały najbardziej stabilny charakter. Były to: powiat poznański oraz Toruń i Kielce. Zmiany najbardziej chaotyczne dotyczyły Zielonej Góry i powiatu zielonogórskiego.

Tabela 1. Wskaźniki intensywności $\left(\mathrm{w}^{\circ}\right)$, szybkości i monotoniczności zmian w strukturze podmiotów gospodarczych w powiatach w latach 2009-2015

\begin{tabular}{|l|c|c|c|c|c|c|c|c|c|}
\hline \multicolumn{1}{|c|}{ Powiat } & 2010 & 2011 & 2012 & 2013 & 2014 & 2015 & $\begin{array}{c}\text { Śednia } \\
\text { intensywność }\end{array}$ & Szybkość & Monotoniczność \\
\hline białostocki & 1,190 & 1,610 & 1,174 & 0,973 & 0,883 & 1,327 & $\mathbf{1 , 1 9 3}$ & $\mathbf{0 , 3 9 9}$ & 0,797 \\
\hline m. Białystok & 0,973 & 1,859 & 1,615 & 0,785 & 0,738 & 1,153 & 1,187 & 0,350 & $\mathbf{0 , 8 1 0}$ \\
\hline gorzowski & 1,349 & 1,127 & 1,678 & 1,414 & 1,312 & 1,601 & $\mathbf{1 , 4 1 4}$ & $\mathbf{0 , 4 3 2}$ & 0,755 \\
\hline m. Gorzów Wielkopolski & 0,774 & 1,581 & 0,484 & 0,522 & 1,384 & 1,105 & 0,975 & 0,291 & $\mathbf{0 , 8 4 4}$ \\
\hline kielecki & 1,591 & 1,450 & 1,425 & 0,789 & 1,349 & 0,864 & $\mathbf{1 , 2 4 5}$ & $\mathbf{0 , 4 2 2}$ & 0,840 \\
\hline m. Kielce & 0,892 & 1,184 & 1,465 & 1,071 & 0,754 & 1,127 & 1,082 & 0,329 & $\mathbf{0 , 9 0 5}$ \\
\hline olsztyński & 1,665 & 1,459 & 1,705 & 1,213 & 1,353 & 1,178 & 1,429 & $\mathbf{0 , 4 0 7}$ & 0,838 \\
\hline m. Olsztyn & 1,116 & 1,524 & 1,882 & 1,880 & 1,423 & 1,494 & $\mathbf{1 , 5 5 3}$ & 0,396 & $\mathbf{0 , 8 8 9}$ \\
\hline opolski & 0,781 & 1,017 & 0,735 & 0,790 & 1,255 & 0,993 & 0,928 & $\mathbf{0 , 3 1 7}$ & 0,802 \\
\hline m. Opole & 0,976 & 1,087 & 1,486 & 0,842 & 1,056 & 0,969 & $\mathbf{1 , 0 6 9}$ & 0,274 & $\mathbf{0 , 8 1 1}$ \\
\hline poznański & 1,130 & 1,330 & 0,975 & 1,171 & 1,170 & 1,079 & 1,143 & 0,370 & $\mathbf{0 , 9 3 8}$ \\
\hline m. Poznań & 1,135 & 0,876 & 1,633 & 1,383 & 1,658 & 1,713 & $\mathbf{1 , 4 0 0}$ & $\mathbf{0 , 3 7 4}$ & 0,851 \\
\hline rzeszowski & 1,749 & 1,185 & 1,009 & 1,031 & 1,771 & 1,244 & 1,332 & 0,407 & 0,763 \\
\hline m. Reszów & 1,441 & 1,247 & 1,941 & 4,146 & 2,223 & 1,249 & 2,041 & 0,503 & 0,875 \\
\hline toruński & 1,342 & 2,099 & 1,392 & 1,896 & 1,611 & 1,110 & 1,575 & $\mathbf{0 , 5 3 1}$ & 0,795 \\
\hline m. Toruń & 1,067 & 1,831 & 2,362 & 1,580 & 1,528 & 1,512 & $\mathbf{1 , 6 4 7}$ & 0,439 & $\mathbf{0 , 9 0 6}$ \\
\hline zielonogórski & 1,372 & 0,894 & 1,346 & 0,663 & 1,345 & 4,133 & 1,625 & 0,487 & 0,592 \\
\hline m. Zielona Góra & 1,212 & 1,234 & 6,409 & 0,907 & 0,880 & 1,654 & 2,049 & 0,501 & 0,647 \\
\hline
\end{tabular}

Źródło: opracowanie własne na podstawie danych GUS. 
Zestawiając wyniki $\mathrm{z}$ analizy intensywności, szybkości i monotoniczności zmian, można zauważyć pewne prawidłowości. Wyniki analizy intensywności i szybkości zachodzenia zmian z niewielkimi wyjątkami wskazują na te same powiaty, określając najwyższe i najniższe tempo zmian strukturalnych. Można zauważyć także, że w miastach centralnych intensywność i monotoniczność zachodzenia zmian są zazwyczaj wyższe niż w powiatach sąsiadujących wymienionych w obszarach. Wyjątkami są powiaty białostocki, gorzowski i kielecki w przypadku intensywności oraz poznański $\mathrm{w}$ zakresie monotoniczności. Jeśli chodzi o szybkość zmian, to zwykle jest ona większa w powiatach otaczających miasto na prawach powiatu, z wyjątkiem Poznania, Rzeszowa i Zielonej Góry.

W drugiej części badania na podstawie analizy logicznej z listy sekcji PKD 2007 wybrano te sekcje, które w największym stopniu prezentowały nowe sektory gospodarki, a więc usługi w dużej mierze oparte na wiedzy. Były to sekcje: J - informacja i komunikacja, sekcja $\mathrm{K}$ - działalność finansowa i ubezpieczeniowa, sekcja L - działalność związana z obsługą rynku nieruchomości, sekcja $\mathrm{M}$ - działalność profesjonalna, naukowa i techniczna oraz sekcja $\mathrm{N}$ - działalność w zakresie usług administrowania i działalność wspierająca.

$\mathrm{Na}$ podstawie działów należących do wybranych wcześniej sekcji utworzono strukturę podmiotów gospodarczych należących do nowych sektorów gospodarki,

Tabela 2. Wskaźniki intensywności $\left(\mathrm{w}^{\circ}\right)$, szybkości i monotoniczności zmian w strukturze podmiotów gospodarczych z sekcji J, K, L, M i N w powiatach w latach 2009-2015

\begin{tabular}{|l|c|c|c|c|c|c|c|c|c|}
\hline \multicolumn{1}{|c|}{ Powiat } & 2010 & 2011 & 2012 & 2013 & 2014 & 2015 & $\begin{array}{c}\text { Średnia } \\
\text { intensywność }\end{array}$ & Szybkość & Monotoniczność \\
\hline białostocki & 0,438 & 0,997 & 1,329 & 0,711 & 0,751 & 0,787 & 0,836 & 2,226 & 0,806 \\
\hline m. Białystok & 0,371 & 1,000 & 1,214 & 0,567 & 0,151 & 0,430 & 0,622 & 1,526 & 0,721 \\
\hline gorzowski & 1,438 & 1,771 & 2,237 & 1,116 & 1,240 & 0,670 & $\mathbf{1 , 4 1 2}$ & $\mathbf{2 , 1 5 6}$ & 0,668 \\
\hline m. Gorzów Wielkopolski & 0,624 & 1,334 & 0,595 & 0,254 & 1,230 & 0,367 & 0,734 & 1,138 & $\mathbf{0 , 7 3 8}$ \\
\hline kielecki & 1,368 & 0,770 & 2,968 & 1,481 & 1,972 & 1,104 & $\mathbf{1 , 6 1 1}$ & $\mathbf{2 , 2 9 7}$ & 0,837 \\
\hline m. Kielce & 1,003 & 0,890 & 0,195 & 0,766 & 0,493 & 0,374 & 0,620 & 1,109 & $\mathbf{0 , 9 1 0}$ \\
\hline olsztyński & 3,399 & 0,993 & 2,524 & 1,544 & 0,930 & 1,209 & 1,766 & 1,935 & 0,840 \\
\hline m. Olsztyn & 0,600 & 0,467 & 0,971 & 0,879 & 0,304 & 0,200 & 0,570 & 1,039 & 0,638 \\
\hline opolski & 1,006 & 0,183 & 0,346 & 0,603 & 1,760 & 0,901 & 0,800 & 1,362 & 0,804 \\
\hline m. Opole & 0,480 & 1,056 & 0,405 & 0,518 & 0,596 & 0,297 & 0,559 & 0,841 & 0,521 \\
\hline poznański & 0,228 & 0,683 & 0,580 & 0,234 & 0,168 & 0,551 & $\mathbf{0 , 4 0 7}$ & 1,013 & 0,716 \\
\hline m. Poznań & 0,393 & 0,815 & 0,112 & 0,038 & 0,401 & 0,522 & 0,380 & $\mathbf{1 , 3 0 7}$ & $\mathbf{0 , 9 4 4}$ \\
\hline rzeszowski & 1,033 & 1,395 & 0,328 & 0,677 & 1,061 & 0,360 & 0,809 & 1,914 & 0,752 \\
\hline m. Rzeszów & 0,433 & 0,868 & 0,511 & 8,467 & 0,914 & 0,435 & $\mathbf{1 , 9 3 8}$ & $\mathbf{2 , 6 4 6}$ & $\mathbf{0 , 8 4 8}$ \\
\hline toruński & 2,993 & 1,968 & 2,314 & 3,287 & 2,193 & 0,943 & 2,283 & 2,740 & 0,840 \\
\hline m. Toruń & 0,907 & 2,375 & 2,666 & 2,403 & 1,496 & 0,535 & 1,730 & 1,929 & 0,780 \\
\hline zielonogórski & 2,508 & 0,549 & 1,982 & 1,022 & 0,330 & 9,195 & 2,598 & 2,788 & 0,443 \\
\hline m. Zielona Góra & 1,018 & 1,916 & 15,688 & 1,056 & 0,760 & 2,613 & $\mathbf{3 , 8 4 2}$ & $\mathbf{3 , 7 8 1}$ & $\mathbf{0 , 7 3 3}$ \\
\hline
\end{tabular}

Źródło: opracowanie własne na podstawie danych GUS. 
która składała się z pięciu wcześniej wymienionych sekcji: J, K, L, M i N. Analogicznie do badania struktury wszystkich podmiotów gospodarczych na podstawie danych z lat 2009-2015 dla badanych powiatów powstało 126 struktur, które poddano analizie intensywności, szybkości i monotoniczności zmian.

Latami, które przyniosły średnio największe zmiany, były 2012 oraz 2013 r. Największą intensywność zmian zanotowano w Zielonej Górze $\left(15,688^{\circ}\right)$, a najmniejszą w Poznaniu $\left(0,112^{\circ}\right)$ - obie wartości dla roku 2012 (tab. 2). Powiatami, w których zanotowano najwyższą średnią intensywność oraz największą prędkość zmian, były Zielona Góra oraz powiaty zielonogórski i toruński. Najmniejszą intensywnością zmian struktury charakteryzował się Poznań oraz powiat poznański, a także Opole oraz Olsztyn. Najniższa szybkość zachodzenia zmian zaobserwowana została w Opolu. Równie niskie wartości rozpoznano w Kielcach i Olsztynie. Najbardziej stabilnym kierunkiem zmian w strukturze charakteryzowały się Poznań oraz Kielce, a także grupa powiatów o zbliżonej wartości monotoniczności: kielecki, olsztyński i toruński. Powiat zielonogórski i Opole miały najniższe wskaźniki monotoniczności, w związku z czym uznać należy, że zmiany zachodzące w tych powiatach miały najbardziej przypadkowy charakter.

Przypatrując się zmianom w strukturze podmiotów gospodarczych z sekcji J, K, L, M i N, można zauważyć, że szybsze i bardziej intensywne przeobrażenia dotyczyły obszarów otaczających powiaty grodzkie. Wyjątkami od tej prawidłowości były, w szczególności, Zielona Góra i Rzeszów, a także w przypadku szybkości zachodzenia zmian - Poznań. O ile zmiany w obszarach centralnych były wolniejsze i mniej intensywne, o tyle zaobserwowano, że miały bardziej stabilny charakter. Jedynie w powiatach białostockim, olsztyńskim, opolskim i toruńskim przeobrażenia struktur gospodarczych nowych sektorów charakteryzowały się wyższym wskaźnikiem monotoniczności niż przyporządkowane im miasta centralne.

\section{Zakończenie}

Zestawiając wyniku obu etapów badania struktury można stwierdzić, że zarysowują się pewne ogólne wnioski. Proces adaptacji struktur podmiotów gospodarczych w wybranych obszarach okazał się bardziej intensywny niż w przypadku procesu adaptacji struktur podmiotów nowych sektorów gospodarki. W przypadku wszystkich podmiotów gospodarczych analiza procesu adaptacji struktur wykazała, że intensywność zmian w strukturze była wyższa w miastach centralnych, odwrotnie niż w przypadku struktur podmiotów nowych sektorów, gdzie w powiatach otaczających miasto centralne zaobserwowano większą intensywność zmian tych struktur. Szybkość zachodzenia zmian, zarówno w przypadku struktur wszystkich podmiotów, jak i struktur podmiotów nowej gospodarki, była większa w otoczeniu niż w miastach centralnych. Zmiany o najbardziej stabilnym charakterze obserwowano w miastach centralnych w analizie obu typów struktur podmiotów gospodarczych. 
Z przeprowadzonych badań wynika więc, że struktury podmiotów gospodarczych nowych sektorów gospodarki szybciej i intensywniej podlegają przekształceniom na obszarach otaczających miasta centralne, natomiast zmiany te mają mniej stabilny charakter niż w miastach centralnych. Rozważania na ten temat mogą stanowić podstawę do dalszych badań nad zauważonymi prawidłowościami.

\section{Literatura}

Adamus W., 2009, Wptyw metropolii na rozwój-społeczno-gospodarczy regionu (podejście metodologiczne). Potencjalne metropolie ze szczególnym uwzględnieniem Polski Wschodniej, Studia KPZK PAN, t. CXXV.

Allen P., Strathern M., Baldwin J., 2006, Evolution, Diversity and Organization, [w:] Garnsey E., McGlade J. (red.), Complexity and Co-evolution, Edward Elgar, Cheltenham, s. 22-60.

Boudeville J.R., 1966, Problems of Regional Economic Planning, Edinburgh University Press, Edinburgh.

Christaller W., 1933, Die Zentralen Orte in Süddeutschland. Eine ökonomisch-geographische Untersuchung über die Gesetzmässigkeit der Vorbereitung und Entwicklung der Siedlungen mit städtischen Funktionen, Jena.

Czyż T., 2009, Koncepcje aglomeracji miejskiej i obszaru metropolitalnego w Polsce, Przegląd Geograficzny, t. 81, nr 4, s. 445-459.

Domański B., 2008, Rozwój polskich metropolii a regiony peryferyjne. Bezpowrotna separacja czy współzależność rozwoju? Rola polskich aglomeracji wobec wyzwań Strategii Lizbońskiej, Studia KPZK PAN, t. CXX, s. 135-143.

Domański R., 2012, Ewolucyjna gospodarka przestrzenna, Wydawnictwo Uniwersytetu Ekonomicznego w Poznaniu, Poznań.

Friedmann J., 1967, A General Theory of Polarized Development, Ford Foundation, Urban and Regional Advisory Program in Chile, Santiago, Chile.

Friedmann J., 1972, A General Theory of Polarized Development, [w:] Hansen N.M. (red.), Growth Centres in Regional Economic Development, Free Press, New York, s. 82-107.

Gaczek W.M., 2009, Gospodarka oparta na wiedzy $w$ regionach europejskich, Studia KPZK PAN, t. CXVIII.

Gaczek W.M., 2010, Miasta jako bieguny rozwoju w polskiej przestrzeni-polaryzacja czy konwergencja. Prace z gospodarki przestrzennej, Zeszyty Naukowe Uniwersytetu Ekonomicznego w Poznaniu, nr 161, s. 88-110.

Gaczek W.M., 2011, Aglomeracja a rozwój regionu, Perspektywy rozwoju regionalnego Polski w okresie programowania po 2013 r. cz. I, Studia KPZK PAN, t. CXL, s. 209-222.

Gaczek W.M., 2013, Obszary metropolitalne jako bieguny wzrostu, [w:] Kisiała W., Stępiński B. (red.), Rola Obszarów Metropolitalnych $w$ polityce regionalnej i rozwoju regionalnym, Wydawnictwo Uniwersytetu Ekonomicznego w Poznaniu, Katedra Ekonomiki Przestrzennej i Środowiskowej, Poznań, s. 22-46.

Hirschmann A.O., 1985, The Strategy of Economic Development, Yale University Press, New Haven.

Kudłacz T., 2009, Duże miasta w Polsce w świetle wybranych wskaźników rozwoju gospodarczego. Potencjalne metropolie ze szczególnym uwzględnieniem Polski Wschodniej, Studia KPZK PAN, t. CXXV, s. 108-120.

Kukuła K., 1996, Statystyczne metody analizy struktur ekonomicznych, Wydawnictwo Edukacyjne, Kraków. 
Metcafe J.S., Foster J., Ramlogan R., 2006, Adaptive economic growth, Cambridge Journal of Economics, vol. 30, s. 7-22.

Moore J.A., 1978, A Measure of Structural Change in Output, Review of Income and Wealth, March, vol. 24 , no. 1 .

Myrdal G., 1957, Economic Theory and Under-developed Regions, Gerald Duckworth \& Co., London. Perroux F.,1955, Note sur la notion de pole de croissance, Economie Appliquee, no. 8, s. 307-320.

Szołek K., 2006, Obszary metropolitalne we wspótczesnej przestrzeni spoleczno-gospodarczej (studium przypadku), Prace Naukowe Akademii Ekonomicznej we Wrocławiu, nr 1135 (Seria: Monografie i Opracowania, nr 173).

Wyżnikiewicz B., 1987, Zmiany strukturalne w gospodarce. Prawidłowości i ograniczenia, PWE, Warszawa. 